\title{
GENERALISED TRAPEZOIDAL RULES WITH ERROR INVOLVING BOUNDS OF THE $n$ TH DERIVATIVE
}

\author{
P. CERONE
}

Abstract. Inequalities obtained for the generalised trapezoidal rules in terms of the upper and lower bounds of the $n$th derivative of the integrand. The Hayashi inequality, or more appropriately an inequality due to Steffensen, is utilised to procure the results which contain earlier expressions as particular cases.

Mathematics subject classification (2000): Primary 26D15, 26D99; Secondary 41A55. quadrature.

Key words and phrases: Hayashi and Iyengar inequalities, Steffensen inequality, Trapezoid type

\section{REFERENCES}

[1] R. P. AgARWAL AND S. S. DRAGOMIR, An application of Hayashi's inequality for differentiable functions, Computers Math. Appl., 32 (6) (1996), 95-99.

[2] P. CERONE AND S. S. DRAGOMIR, Lobatto type quadrature rules for functions with bounded derivative, Math. Ineq. \& Appl., 3 (2) (2000), 197-209.

[3] S. S. DRAGOMIR AND S. WANG, Applications of Iyengar's type inequalities to the estimation of error bounds for the trapezoidal quadrature rule, Tamkang Journal of Mathematics, 29 (1) (1998), 55-58.

[4] K. S. K IYENGAR, Note on an inequality, Math. Student, 6 (1938), 75-76.

[5] G. V. Milovanović AND J. E. PEČARIĆ, Some considerations of Iyengar's inequality and some related applications, Univ. Beograd. Publ. Elektrotehn Fak. Ser. Mat. Fiz., No. 544-576 (1976), 166-170.

[6] D. S. Mitrinović, J. E. PeČArić And A. M. FinK, Classical and New Inequalities in Analysis, Kluwer Academic Publishers, 1993.

[7] D. S. Mitrinović, J. E. PeČARIĆ AND A. M. FinK, Inequalities for Functions and Their Integrals and Derivatives, Kluwer Academic Publishers, 1994.

[8] F. QI, Further generalisations of inequalities for an integral, Univ. Beograd. Publ. Elektrotehn Fak. Ser. Mat., 8 (1997), 79-83.

[9] J. F. STEFFENSEN, On certain inequalities between mean values, and their application to actuarial problems, Skandinavisk Aktuarietidskrift, (1918), 82-97. 